\title{
AZAS KEBEBASAN BERKONTRAK DALAM PERJANJIAN KEAGENAN
}

\author{
Gede Agus Wiadnyana, I Nyoman Putu Budiartha, Desak Gde Dwi Arini \\ Fakultas Hukum, Universitas Warmadewa, Denpasar-Bali, Indonesia \\ gedeaguswiadnyana@gmail.com, budiarthaputu59@gmail.com, arinidesak1966@gmail.com
}

\begin{abstract}
Abstrak
Dalam perjanjian keagenan yang berbentuk perjanjian standar, tampak para pihak tidak bebas untuk menentukan secara bersama-sama isi perjanjian sesuai dengan azas kebebasan berkontrak. Kedudukan pihak prinsipal lebih kuat secara ekonomis bila dibandingkan dengan pihak agen. Tujuan penelitian ini untuk menganalisa azas kebebasan berkontrak dalam perjanjian keagenan serta perlindungan hukum pihak agen berdasarkan azas kebebasan berkontrak dalam perjanjian keagenan. Metode penelitian menggunakan penelitian hukum normatif dengan pendekatan studi kepustakaan (library research). Sumber hukum yang digunakan berupa bahan hukum primer, sekunder, dan tersier. teknik penghitungan atau penelusuran bahan hukum dalam daftar tersebut dikelompokkan atau dikelompokan, dan digunakan metode kualitatif mencatat, mencatat, mengutip, meringkas, dan meninjau sesuai kebutuhan. Selanjutnya, bahan hukum dijabarkan dengan sistematis. Hasil penelitian menunjukkan bahwa Azas kebebasan berkontrak belum sepenuhnya dapat diwujudkan dalam perjanjian keagenan, mengingat perjanjian keagenan tersebut berbentuk perjanjian standar. Kebebasan yang tidak dapat diwujudkan adalah kebebasan para pihak untuk menentukan bentuk perjanjian dan kebebasan para pihak untuk menentukan syarat-syarat, serta perlindungan hukum bagi para agen yang berada dalam posisi lemah dalam perjanjian keagenan. yaitu undang-undang tentang kegiatan usaha para agen. Perlindungan yang diberikan merupakan perlindungan pemerintah terhadap warga negara yang menjadi agen persaingan komersial.
\end{abstract}

Kata Kunci: Azas Kebebasan Berkontrak, Keagenan, Perjanjian.

\begin{abstract}
In an agency agreement in the form of a standard order, it appears that the parties are not free to jointly determine the contents of the agreement with the principle of freedom of contract. The position of the principal is economically stronger when compared to the agent. This research aims to analyze the principle of freedom of contract in agency agreements. legal protection of agents based on the principle of freedom. The research method uses normative legal research with a library research approach. The legal sources used are primary, secondary, and tertiary legal materials. Technique of calculating or tracing legal materials in the list or grouped, and using methods of noting, recording, quoting, summarizing, and reviewing as needed and written systematically. The result of the research indicates that the principle of freedom of contract has not been fully realized in an agency agreement, considering that the agency agreement is in the form of a standard agreement. The freedom that cannot be realized is the freedom of the parties to determine the form of the agreement and the freedom of the parties to determine the conditions, as well as legal protection for agents who are in a weak position in the agency agreement. namely the law on the business activities of agents. Protection provided by the government's protection for citizens who are agents of commercial competition.
\end{abstract}

Keywords: Principle of Freedom of Contract, Agency, Agreement.

\section{PENDAhULUAN}

Fakta yang tidak dapat dipungkiri bahwa antara manusia yang satu dengan manusia yang lain dalam pergaulan di masyarakat tidak dapat hidup sendiri-sendiri, Diantara mereka itu akan selalu berinteraksi satu sama lainnya, terutarna didalam memenuhi kebutuhan hidupnya. Dari interaksi itu kemudian menimbulkan hubungan-hubungan hukum yang diikat oleh suaru perjanjian-perjanjian. Sifat kodrati manusia antara lain hidup berkelompok dalam gugus kesatuan yang disebut masyarakat (Isnaeni, 1996). Dalam sejarah peradaban manusia tidak pernah dijumpai seseorang yang hidup sendiri tanpa tergantung dengan manusia lainnya. Sesuai dengan kodratnya manusia tidak akan bisa hidup sendiri tanpa berinteraksi dengan sesamanya (Asyhadie, 2005). Dengan hakikat hidup seperti itu, maka manusia sebagai makhluk sosial dalam kelompoknya akan selalu bekerjasama dan berinteraksi satu sama lain dalam memenuhi kebutuhan hidupnya. 
Pandangan Hans Krabbe, penganut paham kedaulatan hukum yang mengatakan bahwa asal mula hukum datang dari kesadaran hukum masyarakat (Atmadja, I Dewa Gede Budiartha, 2020). Dalam setiap kehidupan bersama antara manusia dalam masyarakat sudah sejak dahulu kala anggota masyarakat itu telah mengenal adanya hubungan-hubungan diantara mereka yang diikat dengan perjanjian-perjanjian. Mereka saling mengikatkan diri dan saling memberikan prestasinya. Dengan semakin kompleksnya keburuhan hidup manusia, maka semakin banyak pula terjadi macam-rnacam perjanjian dalam hubungan antara anggota masyarakat, terlebih-lebih dalam dunia ekonomi dan perdagangan semakin banyak ragarn dan jenis perjanjian yang dibuat untuk memenuhi kepentingan di bidang itu.

Kitab Undang-Undang Hukum Perdata Selama undang-undang tidak melarang dan tidak melanggar ketertiban dan kesusilaan masyarakat, masyarakat diberi kebebasan seluas-luasnya untuk mengadakan perjanjian yang memuat konten apapun. (Pasal 1337 KUH Perdata), setiap orang bebas memilih pihak yang terikat dengannya untuk membuat kesepakatan, selama pihak tersebut tidak mampu mencapai kesepakatan. Demikian pula, selama undang-undang tidak mengarur bahwa kesepakatan harus dicapai dalam beberapa bentuk, para pihak bebas memilih bentuk kesepakatan yang diinginkan, yaitu kesepakatan yang dicapai secara lisan atau tertulis, atau dibuat dengan cara yang tidak semestinya. atau kontrak yang benar.

Kebebasan masyarakat untuk membuat perjanjian tentang apa saja adalah merupakan salah satu prinsip arau azas didalam Hukum Perjanjian yang dikenal dengan nama Azas Kebebasan Berkontrak, yang dalam bahasa asing dapat disebut Contracts Urijheid, Coruracteer Vrijheid atau Partij qutonomie, atau dalam bahasa Inggris disebut dengan istilah Freedom of Contract (Subekti, 1979). Azas kebebasan berkontrak ini merupakan tiang dari Hukum Perdata khususnya Hukum Perikatan (Buku III Burgerlijke Wetboek). Dengan kata lain, kebebasan berkontrak merupakan isi utama dari sistem civil law. Dalam Hukum Perdata, prinsip kebebasan kontrak yang dianut dalam KUH Perdata edisi ketiga adalah sistem terbuka (material), sedangkan sistem tertutup (material) diadopsi dalam KUH Perdata edisi kedua (Internet of Things Law) (Fuady, 2001). Asas kebebasan berkontrak adalah asas yang mengarur bahwa sepanjang tidak bertentangan dengan hukum, kesusilaan, dan ketertiban umum, pada dasarnya setiap orang dapat membuat suaru kontrak atau perjanjian yang mengandung atau mengandung benruk apapun (Syahrani, 1985). Asas kebebasan berkontrak memiliki arti bahwa setiap orang memiliki kebebasan untuk mencapai kesepakatan sesuai dengan keinginan dan kepentingannya sendiri, Mengingat dalam praktek bisnis terdapat aneka ragam jenis perjanjian, maka tulisan ini memfokuskan kajian tentang azas kebebasan berkontrak dalam perjanjian keagenan. Aktivitas bisnis dalam bidang produksi dan distribusi barang dan jasa sering memanfaatkan agen sebagai perantara dalam kegiatan perdagangan. Transaksi bisnis keagenan yang melibatkan pihak-pihak diikat oleh suatu perjanjian yang namanya perjanjian keagenan.

Hubungan bisnis keagenan umumnya terkait dengan pemasaran suatu produk, dimana pihak prinsipal menunjuk agen disuatu wilayah tertentu guna memasarkan produk yang dihasilkannya. Disamping itu, Latar belakang hubungan bisnis keagenan ini juga dapat terjadi karena pihak asing tidak diperbolehkan menjual atau mengimpor produk secara langsung ke Indonesia. Oleh karena itu, pihak asing yang umumnya disebut prinsipal hams menunjuk agen atau perwakilannya untuk menjual produknya di lndonesia (Simatupang, 1996). Agen adalah seseorang yang diberi wewenang oleh orang lain (disebut prinsipal) untuk mencapai kesepakatan dengan pihak ketiga atas nama prinsipal. Yang paling utama rugas agen itu ialah mengadakan perjanjian antara prinsipalnya dan pihak ketiga (Muhammad, 1986). Dalam kegiatan bisnis, keagenan biasanya diartikan sebagai hubungan hukum di mana seseorang I agen diberi wewenang untuk bertindak atas nama prinsipal 1 orang tersebut dan melakukan transaksi bisnis dengan pihak lain atas namanya. Oleh karena itu, kriteria utama keberadaan agen adalah kekuatan agen sebagai prinsipal.

Hubungan bisnis yang namanya keagenan, merupakan kerjasama bisnis yang berlandaskan pada perjanjian yang dibuat dan ditandatangani oleh kedua belah pihak yang bekerjasama (Fuady, 2001). Hubungan bisnis antara agen dengan prinsipal, Hal tersebut dapat dicapai dengan membuat kesepakatan tertulis, sepanjang isi kesepakatan ditentukan oleh para pihak sesuai dengan kepentingan para pihak, dengan ketentuan tidak melanggar hukum dan etika Pasal 1338 KUH Perdata. Pembuatan perjanjian keagenan pada umumnya dibuat dalam bentuk perjanjian baku (perjanjian standar), dimana klausul perjanjian tersebut dibuat oleh prinsipal, dalam bentuk formulir, dan agen tinggal menyetujui atau menolak perjanjian keagenan tersebut. Perjanjian baku adalah bentuk kesepakatan, yaitu 
kesepakatan antara formula dan formula yang secara sepihak menentukan semua atau sebagian besar substansinya untuk menentukan sepenuhnya kepastian hukum, keamanan dan penguasaan formula dan pihak lain. Format standar dari sebuah transaksi.

Dalam penyelenggaraan bisnis keagenan antara prinsipal dengan agen dilandasi dengan perjanjian keagenan yang pada umumnya berbentuk perjanjian standar, yang klausul (syarat) perjanjiannya telah ditentukan secara sepihak oleh pihak prinsipal. Pihak agen yang ingin menjalin hubungan bisnis dengan prinsipal harus menerima syarat perjanjian tersebut tanpa ada kesempatan untuk menegosiasikan sebelumnya. Dalam perjanjian keagenan yang berbentuk perjanjian standar, tampak para pihak tidak bebas untuk menentukan secara bersama-sama isi perjanjian sesuai dengan azas kebebasan berkontrak. Kedudukan pihak prinsipal lebih kuat secara ekonomis bila dibandingkan dengan pihak agen. Pihak agen posisinya lemah, karena tidak ikut menentukan isi perjanjian.Dalam posisi para pihak tidak seimbang dalam Perjanjian Keagenan, sangat mustahil azas kebebasan berkontrak akan dapat diwujudkan. Untuk melindungi pihak agen yang posisinya lemah, maka perlu campur tangan pemerintah dalam mewujudkan azas kebebasan berkontrak dalam perjanjian keagenan.

Maka berdasarkan uraian diatas, tujuan penelitian ini untuk menganalisa azas kebebasan berkontrak dalam perjanjian keagenan serta perlindungan hukum pihak agen berdasarkan azas kebebasan

\section{METODE PENELITIAN}

Jenis penelitian yang digunakan adalah jenis penelitian hukum normatif. Dengan pendekatan studi kepustakaan. Mengenai sumber bahan hukum yang digunakan terbagi atas bahan hukum utama yang merupakan bahan hukum utama dan menjadi dasar penelitian ini. Bahan Hukum sekunder adalah adalah bahan hukum yang digunakan untuk menunjang atau membantu dalam memberikan pemahaman-pemahaman dan gambaran-gambaran serta teori-teori hukum yang digunakan untuk mengulas dan memecahkan persoalan-persoalan yang akan di teliti di dalam penelitian ini. Bahan Hukum Tersier adalah bahan hukum yang memberikan petunjuk maupun penjelasan terhadap bahan hukum primer dan sekunder. Untuk memperoleh bahan hukum primer, sekunder, dan tersier, maka teknik penghitungan atau penelusuran bahan hukum dalam daftar tersebut dikelompokkan atau dikelompokan, dan digunakan metode kualitatif mencatat, mencatat, mengutip, meringkas, dan meninjau sesuai kebutuhan. Setelah mengumpulkan bahan hukum tingkat pertama dan kedua, mereka akan menggunakan metode pengolahan bahan hukum yang sistematis untuk pengolahan dan analisisnya.

\section{HASIL DAN PEMBAHASAN}

\section{Azas Kebebasan Berkontrak dalam Perjanjian Keagenan}

Terdapat prinsip kebebasan kontrak dalam berbagai literatur tentang hukum perjanjian. Prinsip ini berarti bahwa orang dapat dengan bebas membuat perjanjian sesuai dengan keinginan atau kepentingannya sendiri. Berikut ini contoh kebebasan kontroversial (Ale, 2006).

1) Kebebasan tiap orang untuk memuruskan apakah ia akan membuat perjanjian atau tidak membuat perjanjian

2) Kebebasan tiap orang untuk memitih dengan siapa ia akan membuat suaru perjanjian

3) Kebebasan para pihak untuk menentukan bentuk perjanjian

4) Kebebasan para pihak untuk menentukan isi perjanjian

5) Kekebasan para pihak untuk menentukan cara pembuatan perjanjian. Kebebasan dan kesederajatan individu ini berkembang dengan pesat sejak zaman Renaissance untuk masa yang retatif panjang seperti tercermin pada teori-teori kontrak sosiat dari Thomas Hobbes, John Locke, serta Rousseau. Pengaruhnya demikian kuat dalarn kehidupan hukum, khususnya pada asas-asas hukum perjanjian. Oleh karena itu, penggunaan atau perwujudan azas kebebasan berkontrak dalam perjanjian keagenan perlu diteliti dan dicermati lebih lanjut.

Dalam praktek perjanjian standar (baku), ada kecenderungan kedudukan para pihak tidak seimbang. Pihak konsumen umurnnya kedudukannya lebih lemah dari pada pengusaha yang merumuskan perjanjian standar itu. Begitu pula dalam perjanjian keagenan, dimana pihak agen kedudukannya lebih lernah bila dibandingkan dengan prinsipat, karena agen tidak bebas menentukan pitihan. Berdasarkan pengamatan Djumadi, perjanjian keagenan adatah berbentuk perjanjian standar (baku). Pembuatan perjanjian keagenan pada umumnya dibuat tanpa proses tawar menawar 
(bargaining) yang riil antara prinsipal dengan agen tentang apa yang harus dimuat sebagai isi perjanjian tersebut. Klausula perjanjian keagenan tersebut sudah terlebih dahulu ada dan pihak agen tunggal membaca isi perjanjian keagenan tersebut. Setelah itu ia tinggal menyetujui atau menolak.

Dalam pembuatan perjanjian perlu dilihat real bargaining. Jika dalam pembuatan perjanjian keagenan, pihak agen tidak mempunyai kesempatan untuk mengutarakan pendapat (kehendak) dan kebebasannya dalam menentukan isi/ktausuta dalam suatu perjanjian keagenan, hat tersebut membuktikan bahwa kedudukan para pihak dalarn perjanjian keagenan itu tidak sama (tidak seimbang). Dalam hal ini azas kebebasan berkontrak tidak dipenuhi, atau tidak dapat diwujudkan. Dalam perjanjian keagenan penggunaan perjanjian standar menyebabkan azas kebebasan berkontrak belum sepenuhnya dapat diwujudkan. Secara rinci kebebasan yang tidak dapat diwujudkan adalah

a) Kebebasan para pihak untuk menentukan bentuk perjanjian, karena perjanjian keagenan selalu berbentuk tertulis berupa perjanjian standar.

b) Kebebasan para pihak untuk menentukan isi perjanjian karena dalam perjanjian keagenan isi perjanjian ditentukan secara sepihak oleh pihak prinsipal dan agen sama sekali tidak ikut dilibatkan untuk menentukan isi perjanjian.

c) Kebebasan para pihak untuk menentukan cara pembuatan perjanjian, karena terhadap semua benruk perjanjian keagenan cara pembuatannya telah ditetapkan oleh salah satu pihak, yaitu pihak prinsipal. Sedangkan kebebasan-kebebasan yang masih dapat diwujudkan dalam perjanjian keagenan adalah kebebasan setiap agen untuk memutuskan apakah ia akan membuat perjanjian atau tidak mernbuat perjanjian dan kebebasan setiap agen untuk memilih dengan siapa ia akan membuat perjanjian

Berdasarkan paparan di atas jelas bahwa azas kebebasan berkontrak dalam perjanjian keagenan belum sepenuhnya dapat diwujudkan, terutama kebebasan dalam menentukan isi perjanjian keagenan. Faktanya dalam praktek bisnis keagenan, klausul-klausul/ isi perjanjian keagenan ditumuskan secara sepihak oleh prinsipal tanpa memberi kebebasan dan kesempatan kepada agen untuk ikut merumuskannya. Tidak dapat dipungkiri, dalam kontrak/perjanjian yang berbentuk standar, pelaksanaan atau perwujudan azas kebebasan berkontrak tampak semakin terbatas. Sehubungan dengan semakin terbatasnya perwujudan azas kebebasan berkontrak akibat penggunaan perjanjian standar. Kondisi seperti diuraikan di aras tampaknya terjadi pula di Indonesia. Perjanjian standar telah digunakan secara luas, termasuk dalam transaksi keagenan, sementara Buku III KUH Perdata yang memuat azas kebebasan berkontrak, dewasa ini masih digunakan sebagai dasar hampir seluruh kegiatan transaksi di Indonesia.

Dalam perkembangannya dewasa ini, azas kebebasan berkontrak akan bisa diwujudkan serta capai tujuannya saat semua pihak seimbang. Jika salah satu pihak lemah, pihak yang memiliki daya tawar kuat dapat memaksa keinginannya untuk menekan pihak lain demi keuntungannya sendiri. Keadaan seperti ini juga terjadi pada perjanjian keagenan dalam hubungan hukum antara prinsipal dengan agen. Posisi prinsipal yang pada umumnya perusahaan besar dapat diasumsikan merniliki posisi tawar yang lebih kuat dari pada agen. Disini agen lebih lemah posisinya, sehingga karenanya azas kebebasan berkontrak sulit untuk bisa diwujudkan.

Prinsip kebebasan berkontrak pada awalnya dirancang agar para pihak dapat menegosiasikan kepentingan masing-masing dalam perjanjian tanpa campur tangan pihak lain. Dengan adanya kebebasan kontrak ini diharapkan para pihak dapat mencapai hasil yang maksimal untuk kepentingan masing-masing (Hatta, 1999). Padahal, hal tersebut tidak mungkin dicapai atau dicapai, karena secara alamiah kedua belah pihak memiliki bargaining power yang berbeda, sehingga salah satu pihak dapat menggunakan posisi kuatnya untuk menentukan kemauan dalam perjanjian tersebut untuk kepentingannya sendiri. Pihak lain dengan posisi yang lebih lernah antara lain karena dia membutuhkan partai yang kuat.

Dalam hal prinsipal pihak asing dan agennya berasal dari Indonesia, berdasarkan prinsip Hukum Perdata Intemasional, pihak-pihak dalam perjanjian bebas untuk melakukan pilihan hukum. Dalam perjanjian keagenan dijumpai klausul perjanjian yang memaksa pihak agen mengikuti hukum yang dikehendaki prinsipal. Adapun klausul perjanjian dimaksud adalah berkaitan dengan pelaksanaan perjanjian keagenan ini para pihak sepakat untuk memilih hukum dari pihak prinsipal. Begitu juga dalam hal terjadi sengketa berkaitan dengan pelaksanaan perjanjian. Dari beberapa contoh klausula yang ada dalam perjanjian keagenan sebagaimana disampaikan, menunjukkan bahwa posisi agen sangat lemah, prinsipal yang posisinya lebih kuat dapat menuangkan kehendaknya dalam perjanjian 
tanpa memperhatikan kepentingan dan hak-hak pihak agen. Dalam kondisi seperti itu sangat sulit azas kebebasan berkontrak dapat dilaksanakan atau diwujudkan.

Agar azas kebebasan berkontrak dapat diwujudkan, maka posisi pihak-pihak (prinsipal dan agen) dalam perjanjian keagenan harus seimbang, dalam arti kedudukan pihak-pihak sama kuat. Guna menguatkan posisi agen yang selama ini posisinya lemah, maka sebagai upayanya perlu ada campur tangan pihak pemerintah dengan menerbitkan peraturan perundang-undangan yang pada intinya memuat ketentuan tentang tata cara perumusan klausula baku (standar) serta larangan-larangan bagi pelaku untuk mernuat klausul yang merugikan bagi pihak lainnya dalam perjanjian. Dalam rangka penyusunan undang-undang tentang perjanjian yang bersifat nasional di masa mendatang perlu hal tersebut dipertirnbangkan untuk dimuat. Jika azas kebebasan berkontrak masih tetap akan dianut dalam sistem hukum perjanjian yang akan dibentuk, maka pengertiannya, ruang lingkupnya, pembatasannya, tata cara perumusan, dan penggunaannya perlu ditumuskan secara lebih sempuma. Hal tersebut mengingat penggunaan perjanjian standar, tennasuk perjanjian standar di bidang keagenan tidak dapat dibendung lagi sebagai akibat logis dari tumbuh dan berkembangnya aktivitas bisnis di bidang keagenan.

\section{Perlindungan Hukum Pihak Agen berdasarkan Azas Kebebasan Berkontrak dalam Perjanjian Keagenan}

Sejak diterbitkannya Peraturan Pemerintah No. 36 tahun 1977, departemen teknis telah mengeluarkan keputusan yang mengatur masalah keagenan. Seperti halnya Kementerian Perindustrian, kemudian dikeluarkan Keputusan Menteri Perindustrian Nomor 295 IMISKI 1982 tentang Badan Tunggal. Hanya saja regulasi tersebut tidak mengatur hubungan perdata antara principal dan agent. Keputusan tersebut juga tidak menentukan apakah agen bertindak atas nama prinsipal atau atas namanya sendiri. Mengingat belum adanya peraturan dalam bentuk undang-undang yang khusus mengatur tentang agen, maka landasan hukum yang mengatur hubungan bisnis antara agen dengan prinsipal didasarkan perjanjian yang mereka buat sendiri yang dikenal dengan nama perjanjian keagenan. Upaya yang dapat dilakukan untuk rnemberikan perlindungan hukum bagi agen yang kedudukannya lemah dalam perjanjian keagenan, adalah dengan membuat peraturan perundang-undangan tentang perjanjian keagenan yang berisikan tentang tata cara perumusan dan pembuatan klausul perjanjian keagenan yang didalamnya terkandung unsur perlindungan hukum bagi kedua belah pihak yang memposisikan pihak-pihak dalam posisi yang seimbang. Dengan posisi seimbang seperti itu, diharapkan azas kebebasan berkontrak dapat diwujudkan. Perlindungan hukum agen adalah perlindungan yang diberikan oleh hukum terhadap kegiatan usaha agen, karena aktivitas agen dapat melebihi suatu wilayah, wilayah atau negara. Perlindungan yang diberikan merupakan perlindungan pemerintah terhadap warga negara yang rnenjadi agen persaingan komersial.

\section{SIMPULAN DAN SARAN}

\section{Simpulan}

Azas kebebasan berkontrak belum sepenuhnya dapat diwujudkan dalam perjanjian keagenan, mengingat perjanjian keagenan tersebut berbenruk perjanjian standar, dimana kedudukan pihak- pihak (agen dengan prinsipal) tidak seimbang. Adapun kebebasan yang tidak bisa dicapai adalah kebebasan para pihak untuk menentukan bentuk perjanjian dan kebebasan para pihak untuk menentukan syarat I isi perjanjian. Adapun perlindungan hukum bagi pihak agen yang kedudukannya lemah dalam perjanjian keagenan ini adalah perlindungan yang diberikan oleh undang-undang untuk aktivitas bisnis agen, karena aktivitas agen dapat melebihi wilayah, wilayah, atau negara tertentu. Perlindungan yang diberikan adalah pemerintah melindungi warga negara yang menjadi agen persaingan komersial.

\section{Saran}

Kepada pemerintah, dalam rangka pembentukan Hukum Perjanjian Nasional di masa mendatang, maka perlu segera dibentuk peraturan yang menyangkut perjanjian keagenan. Yang perlu mendapatkan pengaturannya juga adalah menyangkut perjanjian standar, yang substansinya meliputi pengertian, bentuk, tata cara/persyaratan perumusannya, dan pengawasan penggunaannya dalam praktek masyarakat. Kepada pelaku usaha, apabila tentang praktik penggunaan perjanjian standar dan prinsip kebebasan berkontrak sudah diatur dalam peraturan perundang-undangan nasional, maka pelaku usaha atau pihak prinsipal agar di dalam merumuskan klausula perjanjian standar keagenan 
merujuk pada ketentuan perundang-undangan yang berlaku, sehingga tercipta kedudukan yang seimbang antara pihak-pihak (agen dan prinsipal). Dengan kedudukan pihak-pihak yang seimbang, maka diharapkan azas kebebasan berkontrak dapat diwujudkan.

\section{DAFTAR PUSTAKA}

AK, S. (2006). Hukum Kontrak Komersial. PT. Radja Grafindo Persada, Jakarta.

Ale, S. (2006). Hukum Kontrak Internasional. PT. Raja Grafindo Persada, Jakarta.

Asyhadie, Z. (2005). Hukum Bisnis Prinsip dan Pelaksanaannya di Indonesia. PT. Raja Grafindo Persada, Jakarta.

Atmadja, I Dewa Gede Budiartha, I. N. P. (2020). Sistematika Filsafat Hukum. Setara Press, Malang. Fuady, M. (2001). Hukum kontrak: (Dari Sudut Pandang Hukum Bisnis). PT. Citra Aditya Bakti, Bandung.

Hatta, S. G. M. (1999). Sewa Beli Sebagai Perjanjian Tak Bernama Pandangan Masyarakat dan Sikap Mahkamah Agung. PT Alumni, Bandung.

Isnaeni, M. (1996). Hipotek Pesawat Udara di Indonesia. CV. Dharma Muda, Surabaya.

Muhammad, A. (1986). Hukum Perjanjian. PT Alumni, Bandung.

Simatupang, R. B. (1996). Aspek Hukum dalam Bisnis. Rineka Cipta, Jakarta.

Subekti, R. (1979). Hukum Perjanjian. PT. Intermasa, Jakarta.

Syahrani, R. (1985). Seluk-Beluk dan Azas-Azas Hukum Perdata. PT Alumni, Bandung. 